\title{
PENERAPAN KURIKULUM BERTARAF INTERNASIONAL DI MA AMANATUL UMMAH PACET
}

\author{
Chusnul Choimah, M.Pd.I*1, Khoirun Nisa'*2 \\ Dosen PAI Universitas KH. A. Wahab Hasbullah \\ chusnulchotimah@unwaha.ac.id
}

\begin{abstract}
Excellence in International Standard Madrasas in the field of education has competitiveness in international forums and refers to the education standards of one of the other developed countries. The aim of this study is to describe, study and analyze the preparation of educational programs in providing quality learning that is appropriate to the needs and carried out according to the learning program and students to be able to evaluate learning outcomes in accordance with the learning program that has been designed by the teacher. The Amanatul Ummah MBI is one of the madrasas that has its own uniqueness in achieving outstanding achievements and easy students in continuing to study at domestic universities and overseas universities in the scholarship guarantees, on this basis the researchers decided to conduct research related to the curriculum. The research method used in this study is a qualitative research method. Judging from the type, this research is a case study, because this research is conducted intensively, in detail and fundamentally about an institution, where researchers take the case of developing an international curriculum. Talking about the international standard curriculum in public schools is certainly not enough with one strategy, there must be continued and harmonized relations between religious teachers and general teachers and the local community.
\end{abstract} Keyword : Development, International Standard Curriculum.

\section{A. Pendahuluan}

Manusia adalah mahluk sosial. Dalam hubungannya dengan manusia sebagai mahluk sosial, terkandung satu maksud manusia bagaimanapun juga tidak dapat terlepas dari individu yang lain secara kodrat manusia akan selalu hidup bersama. Hidup bersama antara manusia akan berlansung dalam berbagai bentuk komonikasi 


\section{Chusnul Chotimah, Khoirun Nisa'}

dan situasi. Dalam kehidupan semacam inilah terjadi interaksi (belajar). Dari berbagai bentuk interaksi, khususnya mengenai interaksi yang disengaja, ada istilah interaksi idukatif. Interaksi idukatif adalah interaksi yang berlansung di dalam ikatan untuk tujuan pendidikan dan pengajaran. Yang secara khusus disebut interaksi belajar mengajar .

Proses mengajar merupakan inti dari kegiatan pendidikan di sekolah. Agar tujuan pendidikan dan pengajaran berjalan dengan benar, maka perlu mengadnimitrasikan kegiatan-kegiatan belajar mengajar yang lazim disebut administrasi kurikulum. Bidang mengadministrasian ini sebenarnya merupakan pusat dari suatu kegiatan di sekolah. Menurut James B. Brow dalam (B. Subroto, 1997: 3) tugas dan peran guru antara lain menguasai dan mengembangkan materi pelajaran, merencanakan dan mempersiapkan pelajaran sehari-hari mengontrol dan mengevaluasi kegiatan siswa.

Sumber daya manusia dalam pendidikan sangat dibutuhkan dalam mencapai tujuan pendidikan nasional yang berkualitas. Perwujudan pembangunan nasional dipengaruhi adanya kurikulum yang disesuaikan dengan kondisi dan geografis dari suatu Negara. Perubahan kurikulum yang ada di Indonesia terjadi dalam jangka waktu yang tidak terlalu lama. Wakil Presiden Jusuf Kalah di bulan Desember 2014 bahwa “Ganti Mentri Ganti Presiden” di sampaikan sebagai berikut:

"Dunia sudah berubah dan secara tidak langsung sekolah juga mengalami perubahan, cara berhitung waktu zaman sekolah dulu dengan sekarang juga 


\section{Penerapan Kurikulum Bertaraf Internasional di MA Amanatul Ummah Pacet}

berbeda. Tidak ada pembaharuan kurikulum tidak akan bisa mengikuti zaman yang pengetahuannya semakin maju." (hasil risct Wakil Jusuf Kalla dalam sindonews.com/2014)

Kebutuhan peserta didik tidaklah lepas dari kurikulum. Dengan adanya kurikulum yang ${ }^{1}$ terfokus pada kebutuhan peserta didik, diharapkan perkembangan peserta didik dapat mencapai target yang sudah ditentukan oleh pemerintah dengan menyesuaikan kondisi peserta didik 2 lingkungan sekolahnya. Penggunaan kurikulum yang ada di Indonesai sudah ada sejak Indonesia merdeka pada tahun 1947 dan mengalami perubahan kurikulum menjadi kurikulum 2013. Perubahan kurikulum bertujuan untuk melengkapi kekurangan yang ada pada kurikulum sebelumnya.

Kurikulum adalah seperangkat rencana dan pengaturan mengenai isi dan bahan pelajaran serta cara yang digunkan sebagai pedoman penyelenggaraan kegiatan belajar mengajar. standar isi mengenai ruang lingkup untuk mencapai kopetensi lulusan pada jenjang,standar proses mengenai pelaksanaan pembelajaran pada satu satuan pendidikan, standar kopetensi lulusan mengenai kualifikasi kemampuan lulusan mencakup sikap pengetahuan dan keterampilan, standar pendidik dan tenaga kependidikan merupakan prajabatan dan kelayakan maupun mental, standar sarpras pendidikan diperlukan untuk menunjang proses pembelajaran, standar pengelolaan pendidikan mengenai perencanaan, pelaksanaan

\footnotetext{
${ }^{1}$ Sardiman,interaksi dan motivasi belajar mengajar,(bandung;pt rajawali:1970),95

${ }^{2}$ Ramayulis,ilmu pendidikan islam (Jakarta:PT kalam mulia:1992),42
} 


\section{Chusnul Chotimah, Khoirun Nisa'}

dan pengawasan kegiatan pendidikan pada satuan pendidikan, standar pembiayaan pendidikan berdasarkan biaya operasi satuan pendidikan yang berlaku selama satu tahun, standar penilaian pendidikan mengenai mekanisme, prosedur dan instrumen penilaian hasil belajar. kurikulum yang terdiri dari berbagai komponen mempunyai keterkaitan yang diharapkan peserta didik mampu mempunyai standar kecakapan yang sama.

Kurikulum yang terdiri dari berbagai komponen mempunyai keterkaitan yang diharapkan peserta didik mampu mempunyai standar kecakapan yang sama. lembaga pendidikan islam yang memadukan tiga kurikulum dengan jaminan 99\% peserta didiknya dapat masuk perguruan tinggi, baik di dalam negeri maupun di luar negeri hadir ditengah-tengah masyarakat untuk membantu mewujudkan generasi yang mandiri di era globalisasi yang semakin maju, dengan berwawasan IPTEK (ilmu pengetahuan dan teknologi) dan IMTAQ (iman dan taqwa). Keunggulan dalam Madrasah Bertaraf Internasional dalam bidang pendidikan mempunyai daya saing pada forum Internasional dan mengacu pada standar pendidikan salah satu Negara lain yang maju.

Tujuan yang ingin dicapai dari penelitian ini adalah untuk mendeskripsikan, menelaah dan menganalisis penyusunan program pendidikan dalam memberikan kualitas pembelajaran yang sesuai dengan kebutuhan dan di laksanaan sesuai program pembelajaran serta peserta didik agar mampu mengevaluasi hasil belajar sesuai dengan program pembelajaran yang sudah dirancang oleh guru. MBI 


\section{Penerapan Kurikulum Bertaraf Internasional di MA Amanatul Ummah Pacet}

Amanatul Ummah merupakan salah satu madrasah yang memiliki keunikan tersendiri dalam telah mencapai prestasi yang luar biasa dan peserta didik mudah dalam melanjutkan ke perguruan tinggi dalam negeri dan perguruan tinggi luar negeri dalam jaminan kyai, atas dasar itulah peneliti memutuskan untuk melakukan penelitian yang berkaitan kurikulum yang dipadukan dengan judul "pengembangan Kurikulum Bertaraf Internasional Amanatul Ummah pacet.

Sistem Pendidikan Nasional, mendefinisikan kurikulum sebagai “seperangkat rencana dan pengaturan mengenai tujuan, isi, dan bahan pelajaran serta cara yang digunakan sebagai pedoman penyelenggaraan kegiatan pembelajaran untuk mencapai tujuan pendidikan tertentu". Kurikulum sebagai program pengajaran suatu jenjang pendidikan yang digunakan sebagai acuan dan pedoman berlangsungnya sistem pembelajaran di madrasah. Dalam penelitian ini secara khusus dibahas tentang kurikulum. Kurikulum mencakup berbabagai bahan ajar dan pengalaman belajar yang diprogramkan direncanakan dan dirancang secara sistematis. Tujuan yang ingin yang ingin dicapai dari penelitian ini yaitu untuk mendeskripsikan, menelaah dan menganalisis penyusunan program pendidikan dalam memberikan kualitas pembelajaran yang sesuai dengan kebutuhan dan di laksanaan sesuai program pembelajaran serta peserta didik agar mampu mengevaluasi hasil belajar sesuai dengan program pembelajaran yang sudah dirancang oleh guru. 


\section{Chusnul Chotimah, Khoirun Nisa'}

Pentingnya sebuah pengajaran berpengaruh terhadap dampak pada setiap aktivitas madrasah. Kurikulum di negara lain menjadi acuan lembaga pendidikan untuk mempunyai keunggulan dan daya saing yang kuat. Pada penerapan kurikulum di dunia pendidikan mempunyai banyak pengajaran yang diberikan kepada peserta didik sesuai. Penerapan kurikulum dalam proses pendidikan, mengantarkan peserta didik pada tingkat pendidikan yang sudah di rencanakan dan di laksanakan, untuk mencapai jutuan yang ditentukan terutama pada tujuan pendidikan Islam.

Idi (Jihad 2008:2) kurikulum ialah rencana yang dibuat untuk membimbing dalam belajar di sekolah, yang biasanya meliputi dokumen, level secara umum, dan aktualisasi dari rencana-rencana itu dikelas, sebagai pengelaman murid yang telah dicatat dan ditulis oleh seorang ahli pengalaman tersebut ditempatkan dalam lingkungan belajar yang juga mempengaruhi apa yang dipelajari. Untuk memahami definisi kurikulum lebih mendalam sebaiknya dipahami pula bahwa terdapat empat faktor dalam kurikulum, diantaranya: 1) pedoman dalam pengambilan keputusan dan memberikan alternatif yang mendetail; 2) landasan sistematis dalam pengambilan keputusan, memilih, menyusun, dan membuat urutan isi kurikulum; 3) pedoman dalam evaluasi formatif bagi kurikulum yang sedang berjalan; 4) mengidentifikasi kesenjangan pengetahuan seseorang.

Kemampuan guru sangat diperlukan dalam penerapan kurikulum yang dibutuhkan peserta didik. Pengembangan kemampuan dituntut untuk memenuhi 


\section{Penerapan Kurikulum Bertaraf Internasional di MA Amanatul Ummah Pacet}

kebutuhan secara optimal dengan kesiapan peserta didik. Hamalik (2013:238) implementasi kurikulum merupakan pelaksanaan program kurikulum yang telah dikembangkan dalam tahap sebelumnya, kemudian diujicobakan dengan pelaksanaan dan pengelolaan, dengan penyesuaian terhadap situasi lapangan dan karakteristik peserta didik, baik perkembangan intelektual, emosional, serta fisiknya. Dalam menunjang pelaksanaan pembelajaran dengan menghasilkan mutu peserta didik yang berkualitas diperlukan dorongan dari warga sekolah untuk menunjang kualitas peserta didik setelah lulus dan menjadi alumni. Menurut Marsh (Rusman,2012:74) “Terdapat elemen yang mempengaruhi implementasi kurikulum sebagai: dukungan dari kepala sekolah, dukungan dari orang tua, dan dukungan dari dalam diri guru unsur yang utama dalam mencapai tujuan yang ingin dicapai pendidikan.

Penyusunan program pembelajaran merupakan salah satu hal yang harus diperhatikan untuk mempermuda guru dalam mengajar dan peserta didik menangkap materi yang diberikan guru. standar kopetensi dapat dijadikan acuan penyusunan. Penentu keberhasilan dalam kegiatan berkaitan dengan pembelajaran, Persiapan dalam menunjang program pembelajaran untuk membantu guru dalam mengorganisasikan materi atau bahan ajar.

Arikunto (2014:5) pembelajaran merupakan kegiatan jamak yang melalui urutan dari penyusunan kurikulum di pusat, pembuatan analisis materi pembelajaran, pembuatan rencana mengajar, pelaksanaan belajar mengajar, yakni pembelajaran dan evaluasi prestasi belajar. proses pembelajaranyang dimulai dengan adanya persiapan 


\section{Chusnul Chotimah, Khoirun Nisa'}

mengajar ketika kopetensi dan metodologi yang sudah diidentifikasi. Persiapan mengajar merupakan perencanaan yang harus dimiliki pada setiap guru untuk memproyeksikan tentang apa yang akan dilakukan dengan jangka pendek, yang dapat disusun dalam program pembelajaran yang digunakan dalam menunjang berlangsungnya pembelajaran yang menjadi acuan kurikulum.

Pelaksanaan pembelajaran dapat tercapai dengan kemampuan guru dan warga sekolah, berdasarkan kebutuhan guru dan warga sekolah sudah seharusnya menjadikan sebagai salah satu acuan pembelajaran berbasis karakter dan kopetensi untuk membawa nama baik sekolah. Sehingga pandangan masyarakat terhadapa sekolah dapat memberikan nilai positif.

Mulyasa (2015:104) pelaksanaan pembelajaran dapat dilaksanakan berdasarkan kebutuhan dan karakteristik peserta didik, kopentensi dasar pada umumnya. Dalam mencapai tujuan yang sesuai dengan karakteristik, kebutuhan dan perkembangan daerah dan sekolah dengan pelaksanaan terprogram dan sistematis sebagai acuan keberhasilan pembelajaran yang diharapkan sekolah.

Keberhasilan pada suatu rencana pembelajaran dapat ditetepkan dengan mengetahui efektivitas setiap komponen, dengan adanya evaluasi program pembelajaran dilakuakn guna mengetahui kelemahan pada perencanaan yang dibuat. Perkembangan peserta didik dari waktu kewaktu. Dilakukan guna untuk mengukur sejauh mana peserta didik dapat mencapai keberhasilan yang diharapkan 


\section{Penerapan Kurikulum Bertaraf Internasional di MA Amanatul Ummah Pacet}

Widoyoko (2015:10) evaluasi program merupakan rangkai kegiatan yang dilakukan dengan sengaja guna mengetahui tingkat keberhasilan suatu program yang sedang berjalan maupun program yang sudah berlalu, dan sebagai acuan dari tingkat keberhasilan suatu rencana, dengan program pembelajaran yang dibuat oleh guru bisa diketahui kelemahannya. acuan dari tingkat keberhasilan suatu rencana, dengan program pembelajaran yang dibuat oleh guru bisa diketahui kelemahannya.

\section{B. Program Pembelajaran Madrasah Bertaraf Internasional Amanatul Ummah Pondok Pesantren Pacet Mojokerto}

Penentu keberhasilan dalam kegiatan yang berkaitan dengan pembelajaran, di MBI Amanatul Ummah sudah melakukan tahapan dalam penyusunan proses pembelajaran. Hal tersebut sejalan dengan Arikunto (2014:5) yang menyatakan bahwa pembelajaran merupakan kegiatan jamak yang melalui urutan dari penyusunan kurikulum pusat, pembuatan analisis materi pembelajaran, pembuatan rencana mengajar, pelaksanaan mengajar, pembelajaran dan evaluasi prestasi belajar. Dengan adanya urutan penyusunan dalam menemukan ide baru, terdapat dua rapat yang di laksanakan oleh MBI Amanatul Ummah yang pertama rapat kerja lingkup yayasan yang diikuti oleh seluruh lembaga Amanatul Ummah, selanjutnya lingkup MBI yang diikuti oleh tenaga pengajar MBI, sebelum di adakan rapat kerja internal lingkup MBI selama dua hari penuh membahas terkait masalah apapun terutama kurikulum. Pada saat pergantian kurikulum yang menyatakan bahwa pengembangan kurikulum dan penyusunan silabus, pengembangan silabus 


\section{Chusnul Chotimah, Khoirun Nisa'}

disesuaikan dengan kebutuhan setiap pendidikan dan tetap berdasarkan standar kopetensi. Berdasarkan hasil penelitian, penyusunan program pembelajaran dilakukan sebelum ajaran baru mengenai program pembelajaran kaitannya dengan RPP, Silabus yang dimusyawarakan dengan tim MGMP dalam menentukan materi dan kesepakatan bersama, terhadap materi apa yang disampaikan pada minggu pertama, sehingga materi yang diberikan kepada peserta didik sampai menjelang ujian UAS atau UTS, dengan begitu sebelum ajaran baru sudah terprogramkan dan sudah tuntas diawal.

Hasil temuan data juga menunjukkan bahwa program pembelajaran disusun oleh guru mata pelajaran yang kemudian dikoordinasikan dengan ketua MGMP masing-masing dan membahas rencana pembelajaran. Penyusunan yang dilakukan melalui jadwal dan kemudian kumpul MGMP untuk musyawara di awal ajaran baru dalam menentukan materi selama satu tahun, kemudian kesepakatan kitab apa yang digunakan. Dalam proses penyusunan terdapat rapat mingguan, rapat bulanan dan rapat kerja tahunan untuk guru, selain itu terdapat rapat kerja tahunan yayasan yang menjadikanacuan program pada persiapan satu tahun. Program pembelajaran yang disesuaikan dengan kebutuhan peserta didik, yang tetap mengacu konten kurikulum Nasional yang dikembangkan dari Silabus. Setiap program MBI melalui penyusun program pembelajaran pada awal semester yang kaitannya dengan RPP, Silabus yang tidak dapat dilepaskan dari kurikulum dan proses belajar akan menyangkut bagaimana mengajarnya. 


\section{Penerapan Kurikulum Bertaraf Internasional di MA Amanatul Ummah Pacet}

\section{Pelaksanaan Program Pembelajaran Bertaraf Inernasional}

Program pembelajaran merupakan salah satu penentu dalam tercapainya kebutuhan peserta didik untuk menunjang keberhasilan di setiap program yang sudah di rencanakan. Hal tersebut sependapat dengan Mulyasa (2015:104) yang menyatakan bahwa pelaksanaan pembelajaran dapat silaksanakan berdasarkan kebutuhan dan karakteristik peserta didik, kopetensi dasar pada umumnya. Sehingga kurikulum Nasional dan kurikulum Internasional ditanamkan pada peserta didik dalam memenuhi kebutahan agar memiliki nilai plus pada lulusan dengan kemampuan bahasa, sehingga untuk melanjutkan ke Luar Negeri sudah memiliki bekal dari kemampuasn bahasa, tulis, verbal maupun vokal dan termasuk TOEFL Kesuksesan pada program pembelajaran dapat diketahui melalui penyampaian materi dan skill sebagai pengembangan kegiatan pembelajaran yang diberikan guru terhadap peserta didik dalam menunjang keberhasilan program pembelajaran dengan alokasi waktu yang disediakan. Hal tersebut sejalan dengan Suyatmini (2017:61) yang menyatakan bahwa pelaksanaan pembelajaran dikembangkan dengan

rencana pelaksanaan pembelajaran terkait, a) penyajian silabus; b) mengidentifikasi materi pembelajaran untuk siswa; c) penentu tujuan pembelajaran.

Berdasarkan temuan peneliti, melaksanakan yang sudah direncanakan mengenai pelaksanaan terkait jadwal mengajarnya di iplemningkan pada Silabus dan RPP di implementasikan dala pengajaran sesuai jadwal mengajar. Terdapat pembelajaran penalaran peserta didik untuk menjawab dengan peserta didik maju 


\section{Chusnul Chotimah, Khoirun Nisa'}

dan menjelaskan kedepan kemudia diberi soal. Penentu tujuan pembelajaran terdapat kegiatan belajar di MBI Amanatul Ummah yang tergantung dengan kitab Ta'limul mutta'allim kitab karangan islam dahulu yang dipadukan dengan kurikulum formal, terdapat tujuh kunci kesuksesan pada pembelajaran UN, PTN yang dilakukan setiap hari sore malam full day.

Hasil temuan data juga menunjukkan bahwa pelaksanaan program pembelajaran bisa dilakukan di ruang kelas dan di hutan yang memberikan kenyamanan dengan mengembangkan kegiatan pembelajaran selain tiga kurikulum yang dilaksanakan terkait skill organisasi, skil kopetisi, ekstrakulikuler.

Penerapan yang dilakukan dalam pelaksanaan program pembelajaran dari kelas X yang ingin ke Timur Tengah di seleksi terlebih dahulu dan dikelompokkan kelas khusus atau fasqulhos yang di proyeksikan ke Timur Tengah. Dengan memberikan materi, bimbingan khusus, pelajaran tambahan, dan dukungan dengan tenaga pengajar yang kompeten, sehingga peserta didik yang ingin melanjutkan ke Timur Tengah sudah matang.

Alokasi waktu yang disediakan pada sistem pembelajaran Muadalah di MBI Amanatul Ummah dibagi menjadi dua, di pagi pembelajaran diniah muadalah 2 jam pertama dari jam 07.00-08.30 WIB 2x45 menit, dan di malam hari pembelajaran taqiq yang disampaikan oleh para gus dan romo kyai. Untuk kurikulum formal Internasional bahasa asing sudah inklut 45 jam perminggu satu hari ada 8 jam dan di 


\section{Penerapan Kurikulum Bertaraf Internasional di MA Amanatul Ummah Pacet}

hari jumat 5 jam. Istirahat pukul 11.30-12.30 WIB, setelah pembelajaran kurikulum Muadalah dilanjutkan kurikulum Formal.

Peserta didik diberikan kemudahan dalam mendalami dan menjawab soal bahasa arab peserta didik dibekali dengan adanya kelas bahasa arab di setiap hari kamis dan jumat, untuk kelas XI di hari kamis dan di hari jumat kelas X. Bahasa yang diterapkan pada peserta didik dapat dilaksanakan pada pelaksanaan ujian, yang mana kurikulum muadalah di wajibkan menggunakan bahasa Arab saat menjawab soal dan kurikulum formal menggunakan bahasa inggris.

\section{Evaluasi Pembelajaran Madrasah Bertaraf Internasional}

Evaluasi menjadi salah satu faktor penting adanya perbaikan program pembelajaran, karena dengan adanya evaluasi program pembelajaran yang sudah direncanakan dapat mengetahui tingkat keberhasilan pada program pembelajaran dan memperbaiki program kerja di tahun yang akan datang. Evaluasi dapat dilakukan dengan berbagai macam evaluasi diantaranya evaluasi mingguan, bulanan, setiap semester, rapat kerja tahunan. Hal tersebut sejalan dengan Widoyoko (2015:10) evaluasi program merupakan rangkaian kegiatan yang dilakukan dengan sengaja guna mengetahui tingkat keberhasilan suatu program yang sedang berjalan maupun yang sudah berlalu.

Berdasarkan temuan peneliti, melaksanakan yang sudah direncanakan mengenai aspek yang dievaluasi yakni proses dan hasil. Pada proses bagaimana ketika sudah dijalankan kebiasaan kultur MBI Amanatul Ummah kemudian di 


\section{Chusnul Chotimah, Khoirun Nisa'}

evaluasi dari evaluasi bulanan. Proses di kurikulum, ketika program sudah direncanakan dan dituangkan dalam bentuk evaluasi dan akan menunjukkan hasil. Kesuksesan pembelajaran dilakukan dengan meningkatkan perencanaan kerja yang selalu dimonitoring yang dilakukan setiap hari rabu perminggu demi menunjang perbaikan.

Evaluasi guru haflah tahun dengan menyebarkan angket untuk penilaian guru, kaitannya degan memberikan nominasi yang terbaik di guru formal dan guru muadalah. Terdapat penghargaan haflah tahun disatu sisi dapat mengevaluasi kinerja guru, diantaranya penguasaan materi kedisiplinannya, pengelolaan kelas. Untuk peserta didik dilakukan setiap semester, guna memantau keberhasilan materi yang didapat dan diterapkan peserta didik sampai dengan akhir semester.

Penyajian informasi mengenai program pembelajaran yang disusun sebagai dasar pembuatan keputusan, dalam menunjang kesuksesan program pembelajaran yang diterapkan pada peserta didik di setiap kegiatan belajar mengajar berlangsung dengan mengacu pada Silabus dan RPP, sebagai suatu penilai yang perlu dievaluasi yang terdapat pada Tryout, UTS dan UAS untuk mengetahui hasil akhir tercapainya suatu program pembelajaran yang sudah dirancang. Hal tersebut sesuai dengan Widoyoko (2015:10) evaluasi program pembelajaran merupakan proses sistematis yang berkelanjutan untuk mengumpulkan, mendeskripsikan dalam menyajikan informasi mengenai implementasi rancangan program pembelajaran yang disusun guru dan digunakan sebagai dasar pembuatan keputusan, dalam menyusun 


\section{Penerapan Kurikulum Bertaraf Internasional di MA Amanatul Ummah Pacet}

program pembelajaran selanjutnya. Hasil temuan data juga menunjukkan bahwa monitoring pada seluruh kinerja diadakan setiap minggu terdapat rapat implementasi dan perencanaan untuk mengetahui kekurangan atau butuh penyempurnaan. KBM memonitoring pembelajaran ada triwulan ada setiap bulan untuk mengawal tentang kualitas mutu pembelajaran. Kurikulumnya menyampaikan proses kerjanya dan memonitoring dari evaluasi kebijakan, kemudian musyawara guru mata pelajaran.

Evaluasi dapat dilihat dari nilai Tryout dan UTS peserta didik, untuk Tryout dilaksanakan satu bulan sekali kemudian ke UTS evaluasi kedua, kemudian evaluasi ketiga sebelum UAS ada Tryout lagi, sehingga pada saat UAS peserta didik sudah benar-benar matang dan banyak revies materi. Pada evaluasi selanjutnya dari terlaksananya suatu program pembelajaran yakni sistem pembelajaran dikelas, ketika kenaikan kelas ada daur akhlak yang mengetahui siapa saja peserta didik yang kurang akhlaknya di dalam kelas.

\section{E. KESIMPULAN}

Berdasarkan paparan data dan pembahasan, maka dapat disimpulkan sebagai berikut: pertama, penyusunan program pembelajaran sudah sesuai dengan kaidahkaidah yang berlaku hal tersebut dapat dibuktikan dengan adanya program pembelajaran di MBI Amanatul Ummah Pacet Mojokerto seperti workshop, rapat, evaluasi hasil pembelajaran serta dalam penyusunan program pembelajaran guru 


\section{Chusnul Chotimah, Khoirun Nisa'}

mapel dibantu dengan tim MGMP yang ahli di bidangnya sehingga dalam hal ini dapat menunjang kinerja seorang guru dalam menyusun program pembelajaran yang dibutuhkan oleh peserta didik.

Kedua, pelaksanaan program pembelajaran yang ada di MBI Amanatul Ummah Pacet Mojokerto sudah baik. Dimana dalam hal ini pembelajaran disusun sedemikian rupa guna menunjang kebutuhan dari peserta didik itu sendiri. Hal tersebut dapat ditunjang dengan adanya pembelajaran yang tidak hanya dilakukan di dalam kelas tetapi dilakukan di luar ruangan tepatnya di hutan. Selain itu, juga terdapat pengelompokan siswa berdasarkan kebutuhan pembelajaran siswa. Pada pelaksanaan pembelajarannya juga didukung oleh penggunaan bahasa inggris, bahasa arab, bahasa Indonesia. Dengan demikian siswa bisa memahami dari berbagai segi bahasa yang dibutuhkan untuk mengenyam pendidikan sampai ke Luar Negeri.

Ketiga, evaluasi program pembelajaran dilakukan di MBI Amanatul Ummah yakni pada saat pelaksanaan pembelajaran berlangsung dengan tahapan awal yakni memonitoring terlebih dahulu. Aspek yang dievaluasi meliputi proses dan hasil. Untuk lebih memaksimalkan evaluasi biasanya diadakan rapat satu minggu sekali dalam menunjang perbaikan. Evaluasi dilakukan dengan rentan waktu satu tahun sekali untuk guru, sedangkan siswa setiap semester. Setelah itu apabila ada kendala pada pelaksanaannya maka tim guru akan melakukan supervisi demi perbaikan berkelanjutan. 


\section{Penerapan Kurikulum Bertaraf Internasional di MA Amanatul Ummah Pacet}

\section{F. DAFTAR PUSTAKA}

Arikunto, Suharsimi dan Cepi Safruddin Abdul Jabar. 2014. Evaluasi Program Pendidikan. Jakarta: Bumi Aksara.

Hamalik, Oemar. 2013. Dasar-Dasar Ahmadi, Abu. 1986. Metodek Khusus Pendidikan Agama (MKPA). Bandung: Arunco.

Abin, Syamsuddin, Makmun. 2000. Psikologi Pendidikan. Bandung: PT Remaja Rosdakarya.

Dimayati \& Mojiono. 1998. Belajar \& Pembelajaran. Jakarta : PT. Reneka Cipta.

Djamaluddin \& Abdullah Ali. 1997. Kapita Selekta Pendidikan Islam. Bandung: PT. Pustaka Setia.

DEPAG, RI. 1999. Al-Qur'an/Terjemahan. Semarang: PT. Toha Putra.

J.J Hasibun \& Mojiono. 1996. Proses Belajar Mengaja. Bandung: PT Remaja Rosdakarya.

M. Ngalim, Purwanto. 1997. Ilmu Pendidikan Teoritis \& Praktis. Bandung: PT Remaja Rosdakarya.

Nana, Sudjana. 1983. Dasar-Dasar Proses Belajar Mengajar. Bandung: PT. Penerbit Baru.

Nur, Unbiyati. 1997. Ilmu Pendidikan Islam 2. Bandung: PT. Pustaka Setia.

Oemar Malik. 1991. Strategi Belajar Mengajar Berdasarkan CBSA. Bandung: PT. Sinar Baru. . 2001. Kurikulum \& Pembelajaran. Jakarta:PT. Bumi Aksara.

Ramayulis. 1992. Ilmu Pendidikan Islam. Jakarta: PT. Kalam Mulia.

Sardiman. 1970. Interaksi \& Motivasi Belajar Mengajar. Jakarta PT. Rajawali.

Suparno, dkk. 1985. Dimensi-Dimensi Mengajar. Bandung: PT. Sina Sumarsono, Sonny. 2004. Metode Riset Sumber Daya Manusia. Yogyakarat: Graha Ilmia. 


\section{Chusnul Chotimah, Khoirun Nisa'}

Yunus, Namsa. 2000, Methodologi Pengajaran Agama Islam. Ternate: PT. Pustaka Firdaus. 